\title{
PENGEMBANGAN PARTISIPASI MASYARAKAT DALAM PENGAMBILAN KEPUTUSAN DAN PERENCANAAN PENDIDIKAN DI MADRASAH ALIYAH HIDAYATUL MUHSININ LABULIA KECAMATAN JONGGAT KABUPATEN LOMBOK TENGAH
}

\author{
Muchlis Raisin, Untung Waluyo, Muhammad Zulfikar Syuaib (S2apunram.list@gmail.com), \\ (uwaluyo@gmail.com), (Phi_car@unram.ac.id)
}

\begin{abstract}
ABSTRAK: Penelitian ini difokuskan pada beberapa permasalahan, yaitu : (1) bagaimana pemahaman masyarakat tentang partisipasinya dalam pengambilan keputusan dan perencanaan pendidikan, (2) anggota masyarakat yang berpartisipasi, (3) bagaimana bentuk partisipasi masyarakat, (4) faktor yang menunjang partisipasi masyarakat, dan (5) faktor yang menghambat partisipasi masyarakat dalam pengambilan keputusan dan perencanaan pendidikan sebelum dan sesudah dikembangkan. Metode yang digunakan dalam penelitian ini adalah pendekatan kualitatif dengan desain penelitian pengembangan yang dimulai dari tahap studi awal, pengembangan, pengukuran akhir, dan membandingkan hasil studi awal dengan hasil pengukuran akhir. Teknik pengumpulan data yang digunakan : (1) wawancara mendalam, (2) observasi berperan serta, dan (3) dokumentasi. Teknik analisis data yang digunakan : mereduksi data, penyajian data, dan penarikan kesimpulan. Dari hasil analisis data diperoleh temuan penelitian sebagai berikut. Pertama, pemahaman masyarakat tentang partisipasi dalam pengambilan keputusan dan perencanaan pendidikan pada tahap studi awal rendah, setelah pengembangan jauh lebih baik. Kedua, anggota masyarakat hanya terlibat dalam pengambilan keputusan pada tahap studi awal, setelah pengembangan menunjukkan hasil yang sama baik dalam pengambilan keputusan maupun perencanaan pendidikan. Ketiga, bentuk partisipasi masyarakat dilakukan dengan tiga tahapan, hanya dalam pengambilan keputusan pada tahap studi awal. Setelah pengembangan menunjukkan hasil yang sama baik dalam pengambilan keputusan maupun perencanaan pendidikan. Hanya saja terjadi penambahan satu tahapan, sehingga menjadi empat tahapan. Keempat, hasil studi awal menunjukkan adanya lima faktor penunjang partisipasi masyarakat hanya dalam pengambilan keputusan. Setelah pengembangan terungkap dua puluh faktor penunjang partisipasi masayarakat. Kelima, hasil studi awal tercatat tiga faktor penghambat partsipasi masyarakat hanya dalam pengambilan keputusan, Setelah pengembangan, ditemukan sebelas faktor penghambat partisipasi masyarakat baik dalam pengambilan keputusan maupun dalam perencanaan pendidikan.
\end{abstract}

Kata Kunci : Partisipasi Masyarakat, Pengambilan Keputusan dan Perencanaan Pendidikan

\begin{abstract}
This study focused on several issues, namely, (1) how the public's understanding of participation in planning and removal decision education before and after in developed, (2) any member of the community who participate, (3) how the form of community participation, (4) factors which support community participation and (5) factors that inhibit public participation in decision making and planning of education before and after development. The method in this research methods in was with a qualitative approach to research design development. Development research done by conducting initial study, the development, the final measurement, data collection techniques are (1), in-depth interviews, (2), participating observation, and (3), documentation study, the used of technique data analysis are: reducing, data presentation, and conclusion. From the analysis of research on increasing the participation society performance removal decisions and planning of education obtained the following findings. First the are so many society has naver listen the participation of society performance removal decisions and planning of education. Second members of the public only participant in took the conclude at the first step, after the involved this case showing the same result in took the decision. Third, kind of removal decision do by three step. only took in decision at the first step. after the involved showed the same result in took decision while participation in educational planning, only one step added. Fourth initial study results showed that the factors that demonstrate community participation in decision-making, there were five factor, mine while in education planning factors have not to know the patron of community in participation because they have not been involved. Fifth, the results of the initial study, there were three factors that impede people's participation in decision-making in school. Mine while in education planning factor barrier has not appeared for public participation because the public has not been involved. after do the involved, find out eleventh factors in participation of society and took the decision or education planning.
\end{abstract}

Key Words : Society Partisipaties, Removel Decisions, and Planning of Education 


\section{PENDAHULUAN}

Dalam menjalankan fungsinya sebagai lembaga pendidikan, sekolah tidak bisa lepas dari peran serta dan partisipasi masyarakat sekitarnya. Sekolah berada dan dikelilingi oleh masyarakat sehingga mau tidak mau akan terjalin interaksi diantaranya yang mengarah kepada bekerjasama dalam menyukseskan program-program sekolah. Interaksi antara sekolah dan masyarakat akan menghasilkan output sekolah. Oleh karenanya, mutu outputnya akan tergantung dari kualitas interaksi atau kerjasama antara kedua belah pihak.

Undang-Undang tentang Sistem Pendidikan Nasional Nomor 20 Tahun 2003 pada bab IV pasal 8 dan 9 juga menjelaskan tentang hak peran serta masyarakat dalam pendidikan yang menyebutkan bahwa masyarakat berhak berperan serta dalam perencanaan, pelaksanaan, pengawasan, dan evaluasi program pendidikan. Serta masyarakat berkewajiban memberikan dukungan sumber daya dalam penyelenggaraan pendidikan.

Dalam konsep manajemen berbasis sekolah, partisipasi dan peranan masyarakat dalam pendidikan secara optimal sangat diperlukan. Karena sekolah memerlukan dan membutuhkan masukan dan saran dari masyarakat dalam menyusun program yang relevan sehingga tidak hanya cenderung konservatif, akan tetapi sekaligus memerlukan dukungan masyarakat dalam melaksanakan program tersebut, agar dapat melaksanakan perubahan ke arah yang lebih baik.

Indikator penting dalam Manajemen

Berbasis Sekolah ditunjukkan dengan kemandirian, kemitraan, partisipasi, keterbukaan dan akuntabilitas. Selanjutnya hal itu direalisasikan melalui partisipasi atau peran serta masyarakat, khususnya orang tua siswa dalam pengelolaan pendidikan di sekolah. Peran serta itu tidak hanya terbatas pada mobilitas sumbangan dana saja, tetapi lebih substansial pada fungsi-fungsi manajemen di sekolah (Rodliyah, 2013: 5). Pengembangan partisipasi masyarakat dalam pembangunan pendidikan dapat dilakukan dalam berbagai bentuk atau paradigma. Menurut Tilaar (2002: 179) dalam masyarakat pendidikan, hubungan anatara orang tua murid dan guru harus bersifat kooperatif. Karena masyarakat merupakan stakeholders pertama dan utama dari proses pendidikan. Hal ini berarti proses pendidikan, tujuan pendidikan, dan sarana pendidikan, termasuk pula mutu pendidikan merupakan tanggung jawab masyarakat juga.

Dipertegas oleh Pidarta (2005: 6) bahwa lembaga pendidikan tidak boleh mengabaikan keinginan masyarakat sekitar, sebab ia merupakan salah satu bagian dari masyarakat. Lembaga pendidikan harus mampu menyesuaikan diri dengan masyarakat, ia harus toleran dengan masyarakat. Ini berarti lembaga pendidikan harus mengikuti perubahan-perubahan masyarakat.

Lembaga pendidikan merupakan sebuah organisasi sekolah yang membutuhkan dukungan, motivasi, masukan dan saran dari masyarakat guna menentukan arah dan kebijakan serta langkah strategis yang harus diambil dalam menjalankan fungsi organisasinya, termasuk dalam proses pengambilan keputusan dan perencanaan pendidikan yang merupakan hal terpenting bagi organisasi sekolah tersebut. 
pengambilan keputusan merupakan fungsi kepemimpinan yang turut menentukan proses dan tingkat keberhasilan kepemimpinan itu sendiri (Purwanto, 2006: 67). Sedangkan Perencanaan pendidikan dianggap sebagai suatu kegiatan melihat masa depan dalam hal menentukan kebijakan, prioritas dan biaya pendidikan dengan mempertimbangkan kenyataan-kenyataan yang ada dalam bidang ekonomi, sosial, dan politik untuk mengembangkan sistem pendidikan negara dan peserta didik yang dilayani oleh sistem tersebut (Saud dan Makmun, 2011: 11-12).

Pentingnya pengambilan keputusan dalam organisasi sekolah dan perencanaan pendidikan di sekolah tentunya akan menentukan arah tujuan pendidikan di sekolah, yang akan memberikan dampak pada kemajuan dan keberhasilan sekolah dalam melaksanakan tugas mulianya untuk mencetak generasi penerus bangsa yang sesuai dengan harapan bangsa dan negara serta sesuai dengan tujuan pendidikan nasional.

Partisipasi masyarakat yang terbatas pada membayar iuran komite sekolah (SPP) tidaklah cukup untuk membuat sekolah mampu melaksanakan programnya dengan baik guna meningkatkan prestasi sekolahnya agar dapat maju dan melaksanakan perubahan ke arah yang lebih baik. Berdasarkan hasil penelitian yang telah dilakukan oleh Zamroni, ditemukan bahwa masyarakat termasuk orang tua peserta didik yang peduli dengan sekolah anaknya dapat meningkatkan prestasi putera-puterinya di sekolah (Zamroni, 2000).

Namun partisipasi masyarakat dalam dunia pendidikan saat ini masih belum terlihat secara maksimal, akibat kurangnya pemahaman masyarakat akan arti penting partisipasinya dalam pendidikan. Masyarakat menganggap bahwa peranan mereka hanya cukup dengan membayar iuran komite sekolah putra-puterinya saja. Berdasarkan pengalaman peneliti di lapangan atau di MA Hidayatul Muhsini Labulia tempat peneliti mengajar sekaligus sebagai lokasi penelitian, selama ini terlihat bahwa keterlibatan masyarakat dalam dunia pendidikan hanya sebatas pada bentuk partisipasi melalui pembayaran iuran komite atau pembayaran SPP dan pembangunan saja.

Bentuk keterlibatan masyarakat yang lain juga terlihat pada kehadiran mereka dalam rapat wali murid, kegiatan pembagian raport siswa-siswi, pengumuman kelulusan siswa-siswi kelas XII dan dalam kegiatan lepas pisah atau perpisahan kelas XII. Ini berarti bahwa bentuk partisipasi masyarakat yang lainnya masih belum nampak, terutama dalam hal pengambilan keputusan dan perencanaan pendidikan. Karenanya, masyarakat masih belum memahami bagaimana proses dalam kegiatan pengambilan keputusan dan perencanaan pendidikan di sekolah, karena memang masyarakat masih jarang sekali terlihat dalam berbagai kegiatan penting sekolah terutama yang berkaitan dengan proses pengambilan keputusan dan perencanaan pendidikan. Oleh karenanya, bagaimana proses pengambilan keputusan dan perencanaan pendidikan di sekolah tidak banyak diketahui oleh masyarakat.

Hal ini juga diperkuat dengan pendapat Ketua Komite MA Hidayatul Muhsinin yakni Bapak Munawir, S.Pd yang menyatakan bahwa partisipasi masyarakat 
dalam pendidikan yang berkaitan dengan pengambilan keputusan dan perencanaan pendidikan masih sangat jarang dilakukan. Bentuk partisipasi masyarakat yang paling dominan hanya terbatas pada pembayaran iuran komite dan rapat wali murid, dan kegiatan-kegiatan yang berkaitan dengan siswa. Bentuk keterlibatan seperti ini terlihat pada sebagian besar sekolah-sekolah yang berada di desa-desa baik sekolah negeri maupun sekolah swasta termasuk di Madrasah Aliyah Hidayatul Muhsinin Tandek Desa Labulia Kecamatan Jonggat Kabupaten Lombok Tengah.

Berdasarkan hasil observasi awal yang dilakukan peneliti juga terlihat bahwa partisipasi dan peran serta keikutsertaan masyarakat dalam mengembangkan dan memajukan sekolah ke arah yang lebih baik masih kurang, sebagaimana hasil wawancara dan pengalaman peneliti. Sehingga dibutuhkan sosialisasi dan partisipasi dari pihak-pihak sekolah untuk meminta dukungan, dorongan dan kerja sama serta partisipasi masyarakat guna melaksanakan perubahan bagi sekolah menuju ke arah yang lebih baik lagi. Kurangnya partisipasi masyarakat dikarenakan oleh masyarakatnya yang cenderung bersikap dan bersifat konvensional. Mereka merasa bahwa pendidikan bagi anak-anak adalah merupakan tanggung jawab pemerintah dan lembaga pendidikan semata. Apalagi dengan adanya pemberian Dana Bantuan Oprerasional Sekolah (BOS) para orang tua siswa merasa bahwa sekolahlah yang memiliki peranan dan tanggung jawab penting dalam mengurus segala keperluan anak-anaknya terkait dengan kebutuhan pendidikannya. Orang tua siswa hanya beranggapan bahwa mereka hanya tinggal mengantar dan menyerahkan anakanak mereka pada sekolah yang diinginkan dan selebihnya hanyalah tinggal urusan sekolah. Masyarakat juga menjadi pasif dan hanya menunggu dari sekolah baik yang berkaitan dengan input, proses, maupun output.

Berdasarkan uraian teoritis dan empiris di atas, maka dapat disimpulkan bahwa partisipasi masyarakat tersebut perlu dikembangkan dan dikaji secara mendalam, terutama pada sekolah yang partisipasi masyarakatnya masih rendah seperti di Madrasah Aliyah Hidayatul Muhsinin Tandek Desa Labulia Kecamatan Jonggat Kabupaten Lombok Tengah.

Berkenaan dengan permasalahan dan fenomena yang telah dijabarkan di atas, maka peneliti merasa perlu untuk mengkaji dan melakukan penelitian guna mengembangkan partisipasi masyarakat dalam pendidikan khususnya pengembangan partisipasi masyarakat dalam pengambilan keputusan dan perencanaan pendidikan di Madrasah Aliyah Hidayatul Muhsinin Tandek Desa Labulia Kecamatan Jonggat Kabupaten Lombok Tengah. Maka dari itu, peneliti ingin melakukan penelitian dengan judul: "Pengembangan Prtisipasi Masyarakat dalam Pengambilan keputusan dan Perencanaan Pendidikan di Madrasah Aliyah Hidayatul Muhsinin Labulia Kabupaten Lombok Tengah".

Sehubungan dengan latar belakang yang telah dijelaskan di atas, maka dalam penelitian ini difokuskan pada beberapa fokus masalah sebagai berikut : (1) bagaimanakah pemahaman masyarakat tentang partisipasinya dalam pengambilan keputusan dan perencanaan, (2) anggota masyarakat 
mana saja yang berpartisipasi dalam pengambilan keputusan dan perencanaan pendidikan, (3) bagaimanakah bentuk partisipasi masyarakat dalam pengambilan keputusan dan perencanaan pendidikan, (4) faktor apa saja yang menunjang partisipasi masyarakat dalam pengambilan keputusan dan perencanaan pendidikan, dan (5) faktor apa saja yang menghambat partisipasi masyarakat dalam pengambilan keputusan dan perencanaan pendidikan di MA Hidayatul Muhsinin Labulia Kabupaten Lombok Tengah sebelum dan sesudah dikembangkan.

Dari fokus masalah tersebut maka tujuan utama penelitian ini adalah memahami bagaimana pengembangan partisipasi masyarakat dalam pengambilan keputusan dan perencanaan pendidikan di Madrasah Aliyah Hidayatul Muhsinin Tandek Desa Labulia Kecamatan Jonggat Kabupaten Lombok Tengah. Secara operasional, penelitian ini bertujuan untuk mengembangkan dan mendeskripsikan : (1) pemahaman masyarakat tentang partisipasinya dalam pengambilan keputusan dan perencanaan pendidikan, (2) pihak-pihak yang berpartisipasi dalam pengambilan keputusan dan perencanaan pendidikan, (3) bentuk partisipasi masyarakat dalam pengambilan keputusan dan perencanaan pendidikan, (4) faktor yang menunjang partisipasi masyarakat dalam pengambilan keputusan dan perencanaan pendidikan, dan (5) faktor yang menghambat partisipasi masyarakat dalam pengambilan keputusan dan perencanaan pendidikan di MA Hidayatul Muhsinin Labulia Kabupaten Lombok Tengah sebelum dan sesudah dikembangkan.

\section{METODE PENELITIAN}

Berdasarkan fokus dan tujuan penelitian, maka penelitian ini memerlukan kajian yang mendalam guna memperoleh data yang lengkap dan rinci. Jenis pendekatan yang paling sesuai dengan penelitian ini adalah pendekatan kualitatif. Sebagai konsekuensi logis penerapan pendekatan kualitatif, maka ciri-ciri penelitian kualitatif tentang partisipasi masyarakat dalam pendidikan ini adalah : (1) mempunyai latar alami (natural setting) sebagai sumber data langsung, dan peneliti menjadi instrument kunci (the key instrument), (2) bersifat deskriptif, yaitu menggambarkan situasi dan pandangan tentang dubia secara deskriptif, (3) lebih mementingkan proses daripada hasil semata, (4) cenderung menganalisis data secara induktif, dan (5) makna merupakan hal yang esensial (Bodgan dan Biklen, 1998: 107).

Sedangkan desain penelitian dalam penelitian ini menggunakan studi pengembangan. Penelitian pengembangan adalah penelitian yang berusaha untuk mengungkapkan dan mengembangkan keadaan riil pada saat tertentu sehingga nantinya menjadi lebih lengkap dan lebih baik. Hal ini sesui dengan pendapat Seals dan Richey (1994), Borg and Gall (1983: 772) dan Sujadi (2003:164) tentang penelitian pengembangan. Dalam hal ini peneliti mengkaji setiap peristiwa yang terjadi dan konsep-konsep pemikiran tentang peristiwa dan kegiatan masyarakat dalam pendidikan untuk mengembangkan fokus yang diteliti serta mengungkapnya secara mendetail. Penelitian pengembangan dilakukan dengan mengadakan studi awal, pengembangan, pengukuran akhir, dan membandingkan 
antara hasil studi awal dengan hasil pengukuran akhir.

Informan dalam penelitian ini terdiri dari orang tua siswa, alumni, tokoh agama, tokoh masyarakat, kepala dusun, dewan guru dan staf, dan komite sekolah dengan jumlah sebanyak 35 orang. Cara penentuan informan dengan menggunakan tehnik non random sampling dengan jenis metode purposive sampling, yaitu teknik penentuan sampel dengan pertimbangan tertentu (Sugiyono, 2011: 85).

Penentuan informan juga ditempuh dengan menggunakan snowball sampling (teknik bola salju), yaitu teknik penentuan sampel yang mula-mula jumlahnya kecil, kemudian membesar. Ibarat bola salju yang menggelinding yang lama-lama menjadi besar (Sugiyono, 2011: 85). Penentuan informan dengan snowball sampling selaras dengan pendapat Riduwan (2013: 64).

Teknik pengumpulan data yang digunakan adalah : (1) wawancara mendalam, (2) observasi berperan serta, dan (3) studi dokumentasi. Teknik analisis data yang digunakan ialah : (1) mereduksi data, (2) penyajian data, dan (3) verifikasi data dan penarikan kesimpulan (Milles dan Huberman dalam Riyanto, 2007: 32-34). Sedangkan teknik pengabsahan data didasarkan pada empat kriteria, yaitu : (1) kredibilitas, (2) transpermabilitas, (3) dependabilitas, dan (4) konfirmabilitas (Moleong, 1990: 302).

Penelitian ini dilaksanakan dari bulan Maret 2015 sampai bulan Juni 2015. Lokasi penelitian dilakukan di Madrasah AliyahHidayatul Muhsinin Labulia Kecamatan Jonggat Kabupaten Lombok Tengah Provinsi Nusa Tenggara Barat.

\section{HASIL DAN PEMBAHASAN}

Temuan peneliti

tentang

pengembangan partisipasi masyarakat dalam pengambilan keputusan dan perencanaan pendidikan di Madrasah Aliyah Hidayatul Muhsinin Labulia Kecamatan Jonggat Kabupaten Lombok Tengah adalah sebagai berikut.

\section{Pemahaman Masyarakat Tentang Partisipasinya dalam Pengambilan Keputusan dan Perencanaan Pendidikan}

Sebagaian masyarakat yang terdiri dari orang tua siswa, alumni, tokoh masyarakat, tokoh agama, kepala dusun, guru, dan komite sekolah pada awalnya masih banyak yang jarang sekali mendengar bahkan tidak pernah mendengar istilah partisipasi masyarakat dalam pendidikan. Akan tetapi ada juga sebagian masyarakat yang sering mendengan istilah partisipasi masyarakat namun belum mampu untuk memahami sepenuhnya. Dan ada juga masyarakat yang sudah mampu memahami partisipasi masyarakat dalam pendidikan.. Terutama dalam pengambilan keputusan dan perencanaan pendidikan.

Tingkat pemahaman masyarakat tentang partisipasi dalam pengambilan keputusan dan perencanaan pendidikan pada tahap studi awal dapat dilihat pada gambar 1 berikut.

Gambar 1

Tingkat Pemahaman Masyarakat tentang Partisipasinya dalam Pengambilan Keputusan dan Perencanaan Pendidikan

(Tahap Studi Awal) 


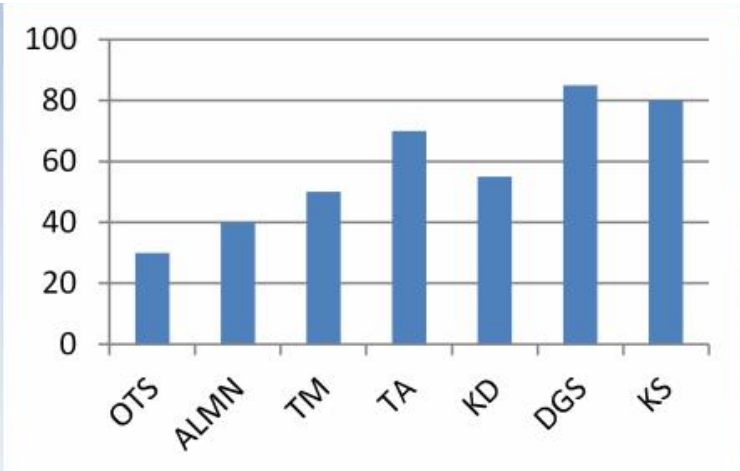

Keterangan:

OTS : Orang Tua Siswa

ALMN: Alumni

TM : Tokoh Masyarakat

TA : Tokoh Agama

KD : Kepala Dusun

DGS : Dewan Guru/Staf

KS : Komite Sekolah

Dari grafik di atas, terlihat bahwa tingkat pemahaman masyarakat tentang partisipasi dalam pengambilan keputusan dan perencanaan penddikan masih rendah. Dimana pemahaman orang tua siswa hanya $30 \%$, alumni $40 \%$, tokoh masyarakat $50 \%$, tokoh agama $70 \%$, kepala dusun $55 \%$, dewan guru dan staf $85 \%$, dan komite sekolah $80 \%$. Sehingga perlu dilakukannya pengembangaan agar tingkat pemahaman masyarakat lebih baik.

Tingkat pemahaman masyarakat tentang partisipasi dalam pengambilan keputusan dan perencanaan pendidikan pada tahap studi awal dapat dilihat pada gambar 2 berikut.

Gambar 2

Tingkat Pemahaman Masyarakat tentang Partisipasinya dalam Pengambilan Keputusan dan Perencanaan Pendidikan (Tahap Studi Akhir)

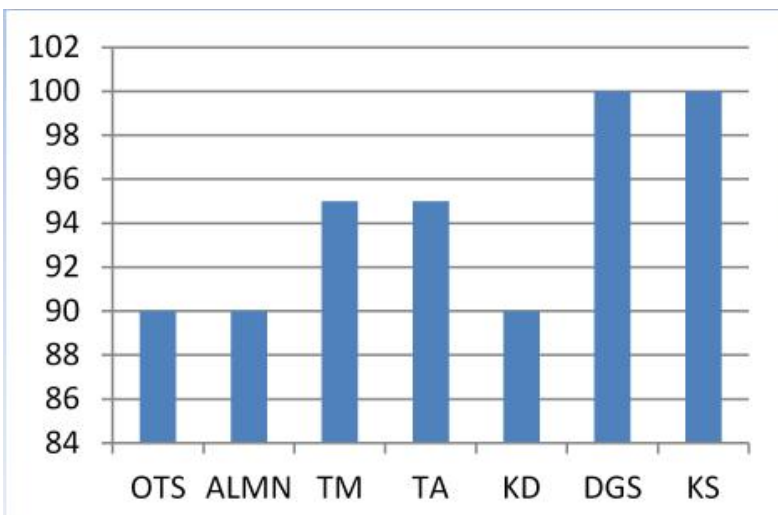

Keterangan:

OTS : Orang Tua Siswa

ALMN: Alumni

TM : Tokoh Masyarakat

TA : Tokoh Agama

KD : Kepala Dusun

DGS : Dewan Guru/Staf

KS : Komite Sekolah

Dari grafik di atas, terlihat bahwa persentase pemahaman masyarakat tentang partisipasinya dalam pengambilan keputusan dan perencanaan pendidikan telah mengalami peningkatan setelah dilakukannya tahap pengembangan. Dimana tingkat pemahaman orang tua siswa meningkat menjadi $90 \%$, alumni $90 \%$, tokoh masyarakat $95 \%$, tokoh agama $95 \%$, kepala dusun $90 \%$, dewan guru dan staf $100 \%$, dan komite sekolah $100 \%$.

Anggota Masyarakat yang Berpartisipasi dalam Pengambilan Keputusan dan Perencanaan Pendidikan

Pada tahap studi awal, hasil yang ditemukan menunjukkan bahwa sekolah telah melibatkan masyarakat (orang tua siswa, alumni, tokoh masyarakat, tokoh agama, tokoh pemuda, kepala desa, kepala dusun, guru, pihak yayasan dan komite) hanya dalam proses pengambilan keputusan saja, akan tetapi tingkat kehadiran dan keaktifan 
masyarakat untuk terlibat masih belum nampak maksimal dan kehadiran masyarakat sering diwakili oleh pihak lain. Hal ini disebabkan karena pemahaman masyarakat yang masih sangat minim terhadap pentingnya berpartisipasi dalam pendidikan, terutama dalam hal keterlibatannya dalam pengambilan keputusan dan perencanaan pendidikan di sekolah. Namun pada saat pengukuran akhir setelah dilakukannya tahap pengembangan, masyarakat tidak hanya dilibatkan dalam pengambilan keputusan saja, akan tetapi juga dalam perencanaan pendidikan dengan tingkat keaktifan dan keterlibatan masyarakat dalam berpartisipasi yang cukup signifikan. Sehingga telihat bahwa adanya upaya dari pihak sekolah untuk selalu berusaha melibatkan masyarakat dalam proses dan kegiatan pengambilan keputusan dan perencanaan pendidikan maupun kegiatan-kegiatan lainnya di sekolah dengan melibatkan seluruh komponen masyarakat yang ada.

\section{Bentuk Partisipasi Masyarakat dalam Pengambilan Keputusan dan Perencanaan Pendidikan}

Bentuk atau cara partisipasi masyarakat dalam pengambilan keputusan adalah dengan terlibat secara langsung dalam menghadiri undangan rapat dari pihak sekolah. Selanjutnya dalam penentuan keputusan dilaksanakan dengan voting atau berdasarkan suara terbanyak dari masyarakat yang hadir. Hasil kesepakatan disampaikan kembali kepada masyarakat dengan diedarkan melalui surat yang dikeluarkan oleh sekolah berdasarkan keputusan rapat yang dibuat dalam surat keputusan kepala sekolah.
Sedangkan bentuk partisipasi dalam kegiatan perencanaan pendidikan di sekolah, masih belum nampak karena masyarakat mengaku belum pernah dilibatkan dalam kegiatan tersebut. Setelah dilakukannya tahap pengembangan oleh pebeliti bersama kepala sekolah, terjadi peningkatan dan perubahan yang cukup signifikan. Masyarakat sudah dilibatkan dalam kegiatan perencanaan pendidikan. Sehingga keterlibatan masyarakat telah optimal baik dalam pengambilan keputusan dan perencanaan pendidikan di sekolah. Cara partisipasi masyarakat setelah dikembangkan dalam pengambilan keputusan dan perencanaan pendidikan adalah tetap sama dengan hasil studi awal dengan terlibat secara langsung dalam menghadiri undangan rapat dari pihak sekolah. Selanjutnya dalam penentuan keputusan dilaksanakan dengan voting atau berdasarkan suara terbanyak dari masyarakat yang hadir. Hasil kesepakatan disampaikan kembali kepada masyarakat dengan diedarkan melalui surat yang dikeluarkan oleh sekolah berdasarkan keputusan rapat yang dibuat dalam surat keputusan kepala sekolah. Namun yang berbeda adalah adanya pengisian surat pernyataan kesanggupan dan tanggungjawab dari pihak yang hadir rapat yang tidak pernah dilakukan sebelumnya sebelum tahap pengembangan. Antusiasme masyarakat untuk hadir dan terlibat berpartisipasi juga cukup tinggi. Hal ini tentunya disebabkan oleh pemahaman masyarakat yang sudah cukup baik terhadap pentingnya partisipasi mereka dalam kegiatan pengambilan keputusan dan perencanaan pendidikan. 
Faktor yang Menunjang Partisipasi Masyarakat dalam Pengambilan Keputusan dan Perencanaan Pendidikan

Hasil studi awal terlihat bahwa faktor yang menunjang partisipasi masyarakat dalam pengambilan keputusan tercatat sebanyak lima faktor (1) rasa memiliki dari masyarakat karena sekolah ini berada di tengah-tengah lingkungan masyarakat, (2) rasa tanggung jawab masyarakat terutama orang tua siswa terhadap sekolah yang telah mendidika anakanak mereka, (3) rasa kepedulian sekolah terhadap masyarakat dengan selalu mengajak masyarakat berpartisipasi dalam (4) rasa ingin tahu masyarakat terhadap proses dan hasil dalam pengambilan keputusan, dan (5) kesadaran masyarakat tentang pentingnya keterlibatan atau partisipasinya di sekolah khususnya dalam kegaiatan pengambilan keputusan. Sedangkan dalam perencanaan pendidikan belum diketahui faktor penunjang partisipasi masyarakatnya untuk berpartisipasi, karena berdasarkan pengakuan masyarakat bahwa mereka belum pernah dilibatkan dalam kegiatan perencanaan pendidikan. Akan tetapi ada anggapan masyarakat bahwa tidak menutup kemungkinan faktor penunjang partisipasi masyarakat dalam pengambilan keputusan ini juga merupakan faktor penunjang partisipasi masyarakat dalam perencanaan pendidikan di sekolah. Namun setelah dilakukannya pengembangan terjadi peningkatan faktor yang menunjang partisipasi masyarakat baik dalam kegiatan pengambilan keputusan maupun dalam kegiatan perencanaan pendidikan yang sudah melibatkan masyarakat. Faktor yang dimaksud diantaranya : (1) kesadaran pribadi masayarakat untuk berpartisipasi, (2) rasa memiliki masyarakat terhadap sekolah, (3) tanggung jawab bersama masyarakat terhadap sekolah, (4) rasa ingin tahu secara langsung masyarakat terhadap hasil keputusan dan perencanaan yang akan ditetapkan, (5) keberadaan lemabaga atau sekolah yang berada ditengah-tengah masyarakat, (6) kepedulian masyarakat terhadap sekolah, (7) kewajiban masyarakat untuk membantu sekolah, (8) antusiasme masyarakat yang tinggi untuk berpartisipasi, (9) tingkat pemahaman masyarakat yang cukup baik terhadap partisipasi, (10) hasrat dan keinginan masyarakat untuk membuat sekolah menjadi lebih maju, (11) tingginya rasa kebersamaan dan kekeluargaan masyarakat Desa Labulia sehingga mudah untuk diajak berpartisipasi, (12) tingkat religuitas masyarakat yang tinggi sehingga memudahkannya untuk memahami pentingnya berpartisipasi terhadap seklah yang memang berbentuk madrasah, (13) tingkat kepedulian masyarakat terhadap sekolah yang cukup tinggi, (14) jarak tempuh masyarakat menuju sekolah yang tidak jauh sehingga memudahkan masyarakat untuk hadir dan berpartisipasi, (15) proses pelaksanaan pengambilan keputusan dan perencanaan pendidikan yang tidak menyulitkan masyarakat dan hasil keputusan dan perencanaan yang tidak memberatkan masyarakat, (16) rasa terimakasih dari masyarakat dengan menghargai sekolah yang telah mendidik putra-putri Desa Labulia, (17) rasa segan dari masyarakat terhadap tokoh pendiri yayasan yang disegani oleh masyarakat sehingga membuat masyarakat harus terlibat jika diajak oleh sekolah, (18) 
adanya upaya sekolah untuk selalu melibatkan masyarakat dalam berpartisipasi, (19) adanya kepedulian daripihak sekolah terhadap masyarakat sehingga mengajak masyarakat untuk selalu terlibat, dan (20) adanya rasa saling membutuhkan antara sekolah dengan masyarakat.

\section{Faktor yang Menghambat Partisipasi Masyarakat dalam Pengambilan Keputusan dan Perencanaan Pendidikan}

Berdasarkan hasil studi awal,
tercatat
sebanyak tiga faktor yang menghambat partsipasi masyarakat dalam pengambilan keputusan yang diantaranya adalah (1) Ketidakhadiran masyarakat karena ada kesibukan lain atau kegiatan lain yang bertepatan dengan undangan pengambilan keputusan di sekolah, (2) Ketidakhadiran masyarakat karena dalam keadaan sakit, dan (3) ketidakhadiran masyarakat karena tidak mendapatkan informasi atau undangan dari sekolah. Sedangkan dalam perencanaan pendidikan belum nampak adanya faktor penghambat partisipasi masyarakat karena masyarakat belum pernah dilibatkan. Setelah dilakukan tahap pengembangan, tingkat pemahaman masyarakat terhadap faktor yang menghambat partisipasi masyarakat meningkat, baik faktor yang menghambat masyarakat dalam pengambilan keputusan maupun dalam perencanaan pendidikan, karena dalam perencanaan pendidikan pihak sekolah telah melibatkan masyarakat untuk berpartisipasi. Faktor yang menghambat partisipasi masyarakat tersebut adalah (1) adanya kesibukan lain yang bertepatan dengan kegiatan di sekolah, (2) krena dalam keadaan sakit sehingga tidak bisa hadir berpartisipasi, (3) karena faktor lupa, (4) alasan karena tidak diundang atau tidak diinformasikan oleh sekolah, (5) undangan yang dikirim pihak sekolah tidak sampai kepada yang bersangkutan, (6) jarak tempuh yang jauh bagi masyarakat yang tinggal di dusun pedalam dan tidak memiliki kendaraan karena wilayah Desa Labulia cukup luas, (7) tingkat ekonomi masyarakat yang bervariatif juga membuat masyarakat terhambat untuk berpartisipasi, (8) masih kurangnya pemahaman masyarakat akan pentingnya pendidikan dan partisipasi dalam pendidikan, (9) karena masyarakat melohat sekolah lain terutama sekolah negeri yang lebih maju dibandingkan sekolah MA Hidayatul Muhsinin membuat masyarakat malas untuk berpartisipasi, (10) adanya doktrin bahwa sekolah tidak bisa maju seperti sekolah negeri dan sekolah lainnya yang memiliki fasilitas yang lengkap dan memadai sehingga masyarakat merasa ragu untuk berpartisipasi, dan (11) adanya doktrin bahwa sekolah tidak berhasil menyelenggarakan pendidikan karena lulusannya banyak yang menganggur dan tidak melanjutkan kuliah. Kesemua faktor yang telah disebutkan di atas, merupakan faktor yang menghambat partisipasi masyarakat dalam pengambilan keputusan dan perencanaan pendidikan di sekolah ataupun yang menghambat partisipasi masyarakat dalam berbagi kegiatan di sekolah yang dirasakan oleh masyarakat setelah adanya tahap pengembangan. Banyaknya faktor penghambat partisipasi masyarakat setelah pengembangan bukan berarti karena gagalnya atau kurang berhasilnya pengembangan yang dilakukan, akan tetapi karena peningkatan pemahaman masyarakat seputar faktor 
penghambat partisipasi mereka setelah adanya pengembangan. Sehingga faktorfaktor penghambat yang belum disebutkan pada saat studi awal karena kurangnya pemahaman masyarakat, tentang partisipasinya dalam dunia pendidikan telah dapat disampaikan pada tahap pengukuran akhir setelah dikembangkan karena tingkat pemahaman masyarakat cukup baik untuk menjelaskan faktor yang menghambat partisipasi mereka dalam pengambilan keputusan dan perencanaan pendidikan di sekolah.

\section{PENUTUP}

\section{Simpulan}

Berdasarkan temuan dan pembahasan hasil penelitian maka dapat ditarik kesimpulan sebagai temuan peneliti tentang pengembangan partisipasi masyarakat dalam pengambilan keputusan dan perencanaan pendidikan di MA Hidayatul Muhsinin Labulia Lombok Tengah sebagai berikut. Pertama, ada keterlibatan masyarakat dalam pengambilan keputusan dan perencanaan pendidikan di sekolah. Kedua, pengambilan keputusan melibatkan berbagai pemangku kepentingan, seperti orang tua siswa, alumni, tokoh masyarakat, tokoh agama, tokoh pemuda, kepala desa, kepala dusun, guru, pihak yayasan dan komite).Tetapi, dalam perencanaan pendidikan mereka tidak pernah dilibatkan. Ketiga, bentuk atau cara partisipasi masyarakat dalam pengambilan keputusan yang terungkap dari penelitian ini adalah (1) menghadiri rapat, (2) menyepakati keputusan berdasarkan suara terbanyak, dan (3) penerbitan surat keputusan (SK) hasil rapat oleh kepala sekolah. Namun bentuk partisipasi dalam perencanaan pendidikan tidak terungkap karena masyarakat tidak pernah dilibatkan. Upaya pengembangan partisipasi masyarakat menunjukkan hasil yang sama dengan hasil studi awal, dan masyarakat telah dilibatkan dalam perencanaan pendidikan di sekolah. Keempat, hasil studi awal menunjukkan ada lima faktor penunjang partisipasi masyarakat dalam pengambilan keputusan, sedangkan dalam perencanaan pendidikan belum terungkap karena masyarakat tidak pernah dilibatkan. Setelah pengembangan terungkap dua puluh faktor penunjang partisipasi masayarakat baik dalam pengambilan keputusan maupun dalam perencanaan pendidikan. Kelima, hasil studi awal, tercatat sebanyak tiga faktor penghambat partsipasi masyarakat dalam pengambilan keputusan. Sedangkan dalam perencanaan pendidikan juga belum terungkap karena masyarakat belum ernah dilibatkan. Setelah dilakukan pengembangan, ditemukan sebelas faktor yang menghambat partisipasi masyarakat baik dalam pengambilan keputusan maupun dalam perencanaan pendidikan di sekolah.

\section{Saran-saran}

a. Kepala Sekolah dan Guru beserta staf MA Hidayatul Muhsinin Labulia Lombok Tengah maupun sekolah-sekolah lainnya, hendaknya menjadikan temuan dalam penelitian ini sebagai pedoman, landasan, dan bahan masukan yang berharga bagi penyelenggaraan dan pengembangan sekolah sebagai bahan evaluasi diri dalam menyelenggarakan pendidikan selama ini agar bisa berupaya memajukan sekolah dengan meningkatkan partisipasi masyarakat dan menjalankannya sesuai kesepakatan 
bersama demi keberlangsungan sekolah kedepannya. Kemajuan sekolah merupakan keberhasilan masyarakat, begitu juga dengan kegagalan sekolah berarti kegagalan masyarakat juga.

b. Komite Sekolah MA Hidayatul Muhsinin Labulia Lombok Tengah dan para komite di sekolah lainnya, hasil penelitian ini akan menjadi bahan pertimbangan dan masukan dalam melaksanakan tugas dan fungsinya sebagai partner sekolah dan sebagai wakil masyarakat serta sebagai penyambung komunikasi anatara sekolah dengan masyarakat.

c. Bagi para anggota masyarakat yang memiliki kepentingan dengan sekolah, terutama masyarakat sekitar sekolah agar kiranya senantiasa selalu mengembangkan dan mengaktifkan partisipasi mereka dalam dunia pendidikan demi memberikan dukungan dana, tenaga, pikiran maupun motivasi yang dapat membantu memajukan sekolah menjadi lebih baik dan lebih baik lagi demi keberlangsungan sekolah selanjutnya.

d. Bagi peneliti dan pemerhati pendidikan, temuan dalam penelitian ini dapat menjadi bahan acuan dan masukan untuk selalu berupaya mengembangkan partisipasi masyarakat secara lebih optimal dan efektif, melalui proses evaluasi dan refleksi secara objektif dan maksimal sehingga peran pemerintah dan masyarakat saling memotivasi dan mendukung.

e. Bagi para peneliti selanjutnya, hasil penelitian ini akan dapat menjadi tolak ukur, gambaran, salah satu acuan dan pedoman dalam mengkaji dan mengembangkan partisipasi masyarakat secara lebih mendalam dengan objek dan variabel yang sama ataupun berbeda karena masih banyak variabel lain yang diduga berpengaruh terhadap partisipasi masyarakat dalam kegiatan pendidikan, khusunya dalam kegiatan pengambilan keputusan dan perencanaan pendidikan.

\section{DAFTAR RUJUKAN}

Bodgan, H.R. dan Biklen, S.K. 1998. Kualitatif Reseach for education : An Intrudaction to Theory and Methodes. Ed.5 London: Allyn and Bacon, inc.

Borg and Gall (1983). Educational Research, An Introduction. New York and London. Longman Inc.

Moleong, L.J. 1990. Metodologi Penelitian Kualitatif. Bandung : PT. Remaja Rosdakarya.

Pidarta, Made. 2005. Perencanaan Pendidikan Partisipatori dengan Pendekatan Sistem (edisi revisi). Jakarta : Rineka Cipta.

Purwanto, Ngalim. 2006. Administrasi dan Sepervisi Pendidikan. Bandung: PT Remaja Rosdakarya.

Riduwan. 2013. Metode dan Teknik Menyususn Tesis. Pengantar Buchari Alma. Bandung : Alfabeta.

Riyanto, Yatim. 2007. Metodologi Penelitian Pendidikan Kualitatif dan Kuantitatif. Surabaya : Unesa.

Rodliyah, Siti. 2013. Partisipasi Masyarakat dalam Pengambilan Keputusan dan Perencanaan di Sekolah. Yogyakarta : Pustaka Pelajar. 
Sa'ud, Udin S dan Makmun, Abin S. 2011. Perencanaan Pendidikan : Suatu Pendekatan Komprehensif. Bandung : PT. Remaja Rosdakarya.

Seels, Barbara B. \& Richey, Rita C. (1994). Teknologi Pembelajaran: Definisi dan Kawasannya. Penerjemah Dewi S. Prawiradilaga dkk. Jakarta: Kerjasama IPTPI LPTK UNJ.

Sugiyono. 2011. Metode Penelitian Kuantitatif, Kualitatif, dan $R \& D$. Bandung: Alfabeta.

Sujadi. 2003. Metodologi Penelitian Pendidikan. Jakarta : Rineka Cipta.

Tilaar, H.A. 2002. Pendidikan Untuk Masyarakat Indonesia Baru. Jakarta: Grasindo. . 2002. Membenahi Pendidikan Nasional. Jakarta: Rineka Cipta.

Undang-Undang No. 20 tahun 2003 tentang Sistem Pendidikan Nasional. Jakarta : Depdiknas 2003

Zamroni. 2000. Paradigma Pendidikan Masa Depan. Yogyakarta : Bigraf Publishing. 
